\title{
Differences in Employee Motivation at Slovak Primary Schools in Rural and Urban Areas
}

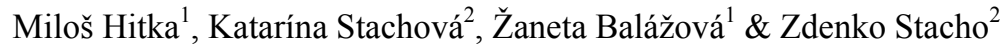 \\ ${ }^{1}$ Faculty of Wood Sciences and Technology, Technical University in Zvolen, Slovakia \\ ${ }^{2}$ School of Economics and Management in Public Administration in Bratislava, Slovakia \\ Correspondence: Miloš Hitka, Department of Enterprise Management, Faculty of Wood Sciences and \\ Technology, Technical University in Zvolen, T. G. Masaryka 24, Zvolen, Slovakia. E-mail: milos.hitka@tuzvo.sk
}

\author{
Received: November 28, 2014 Accepted: January 6, 2015 Online Published: April 27, 2015 \\ doi:10.5539/ies.v8n5p33 URL: http://dx.doi.org/10.5539/ies.v8n5p33
}

\begin{abstract}
In spite of turbulent urbanisation in Slovakia we assume that the $21^{\text {st }}$ century is also a period of differences in value criteria of people living in rural and urban areas. The level of urbanisation, i.e. inhabitant movement from the countryside to towns and the level of suburbanisation, i.e. inhabitant movement from towns to the countryside, are essential urbanisation processes that must be in the centre of our attention in order to understand the individual behaviour in our society more effectively. School and education plays a key role in life of almost all people. This environment affects pupils as well as teachers. Teachers are significant members of the society and influence its further development. Teaching strategies, organisation and management of classroom activities, the use of activation procedures and effective tools for the assessment of educational progress depend greatly on teachers that must be prepared professionally with appropriate qualification. In the paper we deal with the issue of motivational differences of teachers at primary schools (sampling unit consists of 2151 teachers) in Slovakia due to work location (countryside-town). Result of the research, despite small significant differences, is the statement that unified motivation programme for primary school staff can be created.
\end{abstract}

Keywords: employee motivation, differences in motivation factors in rural and urban areas, t-test, Slovakia, teacher

\section{Introduction}

School and education play a key role in life of the youngest generation. Schools create the environment affecting pupils, students and teachers as well. Teachers are an extremely important facet of any society for a multitude of reasons. Teachers are the people who, following required education and relevant regulations, educate the youth who in turn become the leaders of the next generation of people. They are empowered to affect and create ideas, attitudes and samples of behaviour (Kucharčíková, 2014). They set examples which young people try to identify with. So, teachers certainly have a significant mark on the development of young children and even older children alike, as they are teaching them and helping them develop their knowledge so that they can go on in life and be responsible and productive members of society (Urbancová, 2012). Teaching strategies, organisation and management of classroom activities, the use of activation procedures and effective tools for the assessment of educational progress depend greatly on teachers that must be prepared professionally with appropriate qualification (Manniová, 2008).

In the year 1996, D. Hopkins and D. Stern defined the quality of a great teacher in the countries of OECD following the findings of the comparative research carried out in ten countries of OECD. According to these findings qualities of a great teacher should be as follows:

- High level of motivation, responsibility and enthusiasm and interest in particular subject,

- Teacher's perception of their status and their influence on the academic achievements of their students,

- Positive pupil-teacher or student-teacher relationships, love for children,

- Mastery of didactic skills, familiarisation with scientific knowledge,

- Familiarisation with various philosophies of learning and teaching, concepts and various teaching methods,

- Cooperation with other professionals, 
- Permanent feedback, analyses and assessment of their own work, effectiveness and optimisation,

- A good teacher is someone who teaches not only with mind but also with heart (kariková, 2006).

In strategic conception of human resource development in the area of Slovak educational system and personnel strategy in Slovak schools, the interconnection between evaluation, reward system, motivation on one hand and career growth of teachers and pedagogical staff in leading positions,on the other hand,is missing.National professional standards for teachers and pedagogical staff of various career stages and posts can be the basis for the change (Lauermann, 2014).

\section{Issue}

Changes in motivation depend greatly on meeting the people's needs. In the paper we deal with the issue of teacher motivation at primary schools in Slovakia. The statement that being a successful teacher requires extraordinary patience, enthusiasm, creativity, and, above all, love of education is presented in professional literature very often. Decline in the quality of teacher performance and lower sense of satisfaction and subsequent decrease in motivation and personal growth reflect stressful situations that teachers handle day by day (Watt et al., 2014). Moreover, it leads to worse relationship with pupils, school management (Pajtinková \& Gubíniová, 2012), to a lower quality of work and finally to the aversion to teaching (Wahab et al., 2013). Therefore it is necessary to have knowledge of the teachers' behaviour in mentioned situations and what their problem-solving strategies applied in everyday life or stress are and what motivates them at work (Kariková, 2006). Motivation is defined as the process that initiates, guides, and maintains goal-oriented behaviour. At first, instead of direct measurement, specific conditions must be created and subsequently, the changes in behaviour are observed. Following the observed changes, we improve our understanding of the nature of motivation (Sedmák, 2002). In human mind there are the forces that lie beneath motivation (Blašková, 2010). Motivation as the most complex and the most serious skill of managers is described by three key aspects (Vetráková et al., 2011):

1) The first aspect-individual differences in personality of employees that managers and human resource specialists of the organisation try to motivate. Motivation of each employee is very specific and individual activity. Everybody is motivated and at the same time demotivated by something completely different. Employee motivation cannot always affect the approach to work or the improvement of job performance (Stacho \& Stasiak-Betlejewska, 2014). It is likely to be caused by everybody's private desire and ambition, expectations or goals for life (Urbancová, 2012).

2) The second aspect of individual differences is represented by individual differences in personality of managers whose responsibilities are to motivate staff.

3 ) In the third aspect the human motivation changes over time. Owing to the changes in life stages, goals, the needs of people change as well. Human motivation is very individual activity changing over time; therefore all managers should analyse the effectiveness of applied motivation tools regularly and master the art of motivating others. Moreover, good managers will do their best to keep their team motivated only in case they are properly motivated by senior managers (Bolfíková et al., 2010).

Motivation is the driving force behind human behaviour. It is complex and therefore it does not represent a valid way to understand human personality (Stacho \& Stachová, 2010). If motivation was the quality, people naturally have, it would stay constant during their life. However, motivation is affected by various factors and that is why it changes throughout life. Our willingness to work hard and help the company to reach the goal can increase when our work is worth the effort (Niermeyer \& Seyffert, 2005).

Forasmuch as teaching quality improvement in Slovakia is one of the social and political priorities, teacher motivation should be at the forefront of the effort to support our school reform (Linhartová \& Urbancová, 2012). It is extremely difficult to motivate successfully and keep the teachers in school motivated. Primarily, teacher should be a person with creative approach to teaching that loves children and work. When teachers allow themselves to become motivated, the positive energy within them will light up and reach into every corner of their life (László, 2004). The UNESCO document focused on the changing role of teachers (Gable-Porter, 1987) shows that teachers starting their career must be aware of the fact that teacher education is a continuous and cyclic process and preparation for a teaching career is only the beginning of formal training. The aim of the consistent teaching policy should ensure that teacher education will be well organised, continuous and coordinated process with the preparation of teachers at the beginning and lifelong education throughout their professional career (Wosnitza, et al., 2013). Preparation of teachers and their further education must be integrated and must create a lifelong learning system (Turek, 2008). 
Fact that more than a half of Slovak teachers speak about extraordinary low salaries is alarming. Slovak reward system for teachers does not regard the quality of teaching process and therefore it ignores one of the most important tools of teacher motivation affecting their performance. Furthermore, it can also result in hiring high quality teachers who are keen to further their careers. Slovak reward system for teachers is based on education level achieved, career stages and length of teaching practice. Beginning teacher workshops (so-called adaptation education), teacher attestation (gaining 30 or 60 credit points) and the length of teaching practice can affect the career stage and can be taken into account when teacher quality is assessed (Šatanová et al., 2014). Within the Organisation for Economic Co-operation and Development (OECD) Slovakia is the country with the lowest ratio of salary after 15 years of experience to earnings for full-time, full-year workers with tertiary education aged 25 to 64. It proves that Slovak teachers' salaries lag behind not only those in other developed countries but also behind salaries in other areas in Slovakia (http://www.ineko.sk/clanky/publikacie/Financneodmenovanieucitelov a učiteliek.pdf).

Psychological surveys focused on teacher motivation should warn us. Recent results have shown that at least 30 per cent of Slovak teachers suffer from burnout (http://www.sme.sk/c/2189746/takmer-tridsat-percent-ucitelovuci-bez-motivacie.html\#ixzz2KV3B9u6s). Moreover, graduates of universities specialised in Pedagogy have the burnout symptoms. Factors causing burnout in that specific environment in Slovakia are, above all, low salary, social status and long-term problems unlikely to be resolved soon. Burnout is a psychological term that refers to long-term exhaustion and diminished interest in work, i.e. teachers are not more able to motivate their pupils and subsequently to develop their intellectual traits. On the other hand, burnout of teachers is affected also by student lack of discipline, growing number of students per class, integration of students with special needs into regular classrooms and chronic lack of trained teachers as well. Burnout phenomenon is a problem appearing in Slovakia as well as in other post communist countries.

\section{Methodology}

The objective of the paper was to compare the importance and the needs of motivation factors at primary schools in Slovakia and to define potential significant differences between teachers in rural and in urban areas. For analysing motivation factors in organisation a general questionnaire as a tool of inquiry was used. The questionnaire consisted of 30 closed questions (Hitka, 2009, p. 149). The questionnaire was divided into two parts. The first part was focused on socio-demographic and qualification characteristics of employees in the organisation in the rural and urban area. By means of this part we acquired information about respondents relating to their age, sex, number of years at work in the organisation, completed education, and job position. Individual motivation factors through which we can acquire information about characteristics of work environment, working conditions, employee appraisal and reward system, about human resources management, health and social care system and system of employee benefits as well as information about employee satisfaction or dissatisfaction, value orientation, relation to work and enterprise or co-workers' relationship are included in the second part of the questionnaire (Zámečník, 2007). Motivation factors are in alphabetical order not to affect respondents's decision. Respondents evaluated individual motivation factors in the questionnaire by one of the five levels of importance from a pre-defined 5-point rating scale, 5 - very important and 1 unimportant.

Table 1. Scale of an order of motivation factors according to their importance

\begin{tabular}{cccccc}
\hline & 5 & 4 & 3 & 2 & 1 \\
\hline Desired state of motivation & very important & important & neutral & slightly important & unimportant \\
Real state of motivation & very satisfied & satisfied & neutral & somewhat satisfied & dissatisfied \\
\hline
\end{tabular}

Source: own data processing.

The total number of teachers (full-time, part-time) at state, private and church schools in Slovakia is 35006 (18 981 in urban areas, 16025 in rural areas), therefore we could not analyse all respondents (http://portal.statistics.sk/files/Odbory/odb_410/el_publikacie/1_demostav2012.pdf). Larger sample sizes generally lead to higher level of accuracy and confidence in results but, on the other hand, to increasing costs of measurement. Therefore it is considered important to find balance of desired accuracy and confidence, on one hand and costs, on the other hand, hence, the adequate sample size in relation to desired accuracy and effectiveness is set. Statistics formula, where $\mathrm{n}$ is a function of desired accuracy and confidence at estimating 
particular stimulus in population was used to calculate minimum sample size (n). The equation is as follows (Scheer, 2010),

$$
n=\frac{z_{\alpha / 2}^{2} \cdot \sigma_{x}^{2}}{\Delta_{x}^{2}}
$$

where:

n-samplesize,

$\mathrm{z}_{\alpha / 2}-$ critical value of a standard normal random variable $\mathrm{z}(1.96$ for $\alpha=0.025)$,

$\Delta \bar{x}$-desired absolute accuracy,

$\sigma_{x}$-standard deviation.

For example, with the $95 \%$ confidence (ensured with critical value $\mathrm{z}_{0.025}=1.96$ ), desired accuracy $\Delta \bar{x}=0.05$ and response variability specified by variance $\sigma_{x}^{2}=0.6$ (according to the scale of an order of motivation factors), minimum sample size of respondents is as follows:

$$
n=\frac{1.96^{2} * 0.6}{0.05^{2}}=922 \text { respondents }
$$

Responses of 922 teachers working at schools in rural areas and 922 teachers working at schools in urban areas will suffice to provide desired accuracy and confidence. If the level of desired accuracy was higher, for example $\Delta \bar{x}=0.01$ and the confidence will stay the same, the sample size would increase fundamentally to 23,050 questionnaires. The research with mentioned sample size cannot be carried out in our conditions considering costs, time and also seriousness of data acquisition. Finally, 1,004 teachers working at schools in rural areas and 1,004 teachers working at schools in urban areas throughout Slovakia were engaged in the research and completed the questionnaire, whereby we meet criteria for minimum sample size.

Questionnaires were evaluated using the programme STATISTICA 7. Descriptive statistics was used to describe the populations. Basic statistical characteristics were calculated for each motivation factor. They reduced information about the property of populations to a smaller number of numerical characteristics and made mutual comparison of studied populations easier. Each motivation factor (quantitative feature) was described summarily by basic characteristics: levels-average $\bar{x}$ and variability-standard deviations $\mathrm{s}_{\mathrm{x}}$ and coefficients of variation. Subsequently the results were compared by means of inductive statistics. Besides simple comparison of descriptive characteristics, considering the selected type of obtained data, testing the equality of means and standard deviations of populations was carried out. The purpose of testing is to verify statistical significance of differences in averages and standard deviations of individual motivation factors in representative sampling units so that the fact that detected differences of descriptive characteristics at the selected level of significance $\alpha=$ 0.05 were not caused only by the mistake made by representative sampling, was eliminated. The null hypothesis vs. the alternative hypothesis was tested, they were as follows:

$$
H_{0}: \mu_{1}=\mu_{2} \quad \text { vs. } \quad H_{1}: \mu_{1} \neq \mu_{2}
$$

$\mathrm{H}_{0}$ : we suppose that mean of populations of studied motivation factors are equal (therefore we suppose that the difference between them, if any, is owing to the random variation of results).

$\mathrm{H}_{1}$ : we suppose that mean of populations of studied motivation factors are not equal (therefore we suppose that the difference between them, if any, is not owing to the random variation of results).

The Student's t distribution was used as a test criterion. It was as follows (in case variances are equal):

if $\sigma_{1}^{2}=\sigma_{2}^{2} ; \mathrm{X}_{1}$ and $\mathrm{X}_{2}$ are independent,

$$
t=\frac{\bar{x}_{1}-\bar{x}_{2}}{\sqrt{\frac{n_{1} \cdot s_{1}^{2}+n_{2} \cdot s_{2}^{2}}{n_{1}+n_{2}-2} \cdot \frac{n_{1}+n_{2}}{n_{1} \cdot n_{2}}}}
$$


and in case variances are different if $\sigma_{1}^{2} \neq \sigma_{2}^{2} ; \mathrm{X}_{1}$ and $\mathrm{X}_{2}$ are independent,

$$
t=\frac{\bar{x}_{1}-\bar{x}_{2}}{\sqrt{\frac{s_{1}^{2}}{n_{1}}+\frac{s_{2}^{2}}{n_{2}}}}
$$

In the end of the test we comparedttot $\mathrm{\alpha}_{\alpha / 2 ; \mathrm{f}}$ andin case $t \leq t_{\alpha / 2 ; f}, \mathrm{H}_{0}$ was not rejected and the difference was not

considered significant but in case $t>t_{\alpha / 2 ; f} \mathrm{H}_{0}$ was rejected at the level of significance of $5 \%$ and the alternative hypothesisH1was accepted (http://rimarcik.com/navigator/n-interval.html).Using up-to-date IT technology we can calculate error $\alpha$, so-called $\mathrm{p}$-value.In case $\mathrm{p}>0.05$, null hypothesisH 0 is not rejected and in case $\mathrm{p}<0.05$, null hypothesis $\mathrm{H} 0$ is rejected.

\section{Results and Discussion}

Majority of respondents (93\%) were females. Slovak schools have been over-feminised for a long time due to many factors mostly related to low salaries. Regarding the age the main part of teachers belongs to the group aged 41-50 and the length of their teaching practice is more than 10 years. Regarding education more than $85 \%$ ofrespondents completed the first or the second degree of the university study.

On the basis of results gained in the research (Table 2) we can define the order of 10 most required factors in the urban and rural areas. The most important motivation factor in both groups (town-countryside) is job security, likely to reflect current economic situation and financial recession. When comparing to our previous research studies (Hitka et al., 2014, Hitka et al., 2012, Hitka \& Balážová, 2015) but also to other authors (Stacho et al., 2013), where job security belongs to lower levels of needs in a person's hierarchy of needs, mentioned result was expected. Employees are willing to work in worse working conditions in order to keep a job. The next most important motivation factor is the group of factors consisting of communication at work and work environment (communication in the workplace, good work team, atmosphere in the workplace, supervisor's approach, work environment and job performance).

Table 2. Rating scale of an order of motivation factors according to their importance

\begin{tabular}{cccclc}
\hline \multicolumn{4}{c}{ Urban areas } & \multicolumn{5}{c}{ Rural areas } \\
\hline S.N. & \multicolumn{1}{c}{ Motivation factor } & $\varnothing$ & S. N. & \multicolumn{1}{c}{ Motivation factor } & \multicolumn{1}{c}{4.89} \\
\hline 1 & Job security & 4.88 & 1 & Job security & 4.83 \\
2 & Good work team & 4.87 & 2 & Workplace safety & 4.83 \\
3 & Atmosphere in the workplace & 4.71 & 3 & Supervisor's approach & 4.72 \\
4 & Communication in the workplace & 4.66 & 4 & Communication in the workplace & 4.71 \\
5 & Work environment & 4.61 & 5 & Individual decision making & 4.71 \\
6 & Basic salary & 4.58 & 6 & Fair appraisal system & 4.67 \\
7 & Job performance & 4.53 & 7 & Atmosphere in the workplace & 4.67 \\
8 & Workload and type of work & 4.53 & 8 & Mental effort & 4.67 \\
9 & Fringe benefits & 4.47 & 9 & Recognition & 4.67 \\
10 & Supervisor's approach & 4.47 & 10 & Basic salary & \\
\hline
\end{tabular}

Note. Significant factors are in bold, identical motivation factors in rural and urban areas in italics.

Source: own data processing. 
Table 3. Reviewing of significant difference of the level of teacher motivation in rural and urban areas

\begin{tabular}{|c|c|c|c|c|c|}
\hline S.N & Motivation factor & $\begin{array}{c}\text { Urban } \\
\text { areas }\end{array}$ & $\begin{array}{l}\text { Rural } \\
\text { areas }\end{array}$ & t-value & $\mathrm{p}$ \\
\hline 1 & Atmosphere in the workplace & 4.67 & 4.71 & -0.33 & 0.744 \\
\hline 2 & Good work team & 4.56 & 4.87 & -2.71 & 0.009 \\
\hline 3 & Fringe benefits & 4.61 & 4.47 & 0.72 & 0.472 \\
\hline 4 & Physical effort at work & 3.88 & 3.5 & 1.28 & 0.205 \\
\hline 5 & Job security & 4.89 & 4.88 & 0.21 & 0.833 \\
\hline 6 & Communication in the workplace & 4.72 & 4.66 & 0.47 & 0.638 \\
\hline 7 & Name of the company (Name of the school) & 4.18 & 3.58 & 1.76 & 0.044 \\
\hline 8 & Opportunity to apply one's own ability & 4.65 & 4.42 & 1.23 & 0.226 \\
\hline 9 & Workload and type of work & 4.47 & 4.53 & -0.35 & 0.727 \\
\hline 10 & Information about performance result & 4.41 & 4.29 & 0.65 & 0.518 \\
\hline 11 & Working time & 4.44 & 4.29 & 0.75 & 0.457 \\
\hline 12 & Work environment & 4.5 & 4.61 & -0.64 & 0.522 \\
\hline 13 & Job performance & 4.59 & 4.53 & 0.35 & 0.728 \\
\hline 14 & Career advancement & 4.18 & 4.18 & -0.03 & 0.976 \\
\hline 15 & Competences & 4.41 & 4.16 & 1.04 & 0.304 \\
\hline 16 & Prestige & 3.88 & 3.71 & 0.51 & 0.609 \\
\hline 17 & Supervisor's approach & 4.83 & 4.47 & 2.18 & 0.034 \\
\hline 18 & Individual decision making & 4.71 & 4.32 & 2.00 & 0.041 \\
\hline 19 & Self-actualization & 4.61 & 4.32 & 1.53 & 0.131 \\
\hline 20 & Social benefits & 4.41 & 4.08 & 1.24 & 0.221 \\
\hline 21 & Fair appraisal system & 4.71 & 4.39 & 1.5 & 0.138 \\
\hline 22 & Stress (stress elimination, workplace safety) & 4.83 & 4.45 & 2.34 & 0.023 \\
\hline 23 & Mental effort & 4.67 & 4.24 & 1.87 & 0.037 \\
\hline 24 & Mission of the school & 4.59 & 4.29 & 1.21 & 0.232 \\
\hline 25 & Region's development & 4.29 & 4.13 & 0.66 & 0.513 \\
\hline 26 & Education and personal growth & 4.28 & 4.34 & -0.32 & 0.748 \\
\hline 27 & Relation to the environment & 4.47 & 4.45 & 0.13 & 0.896 \\
\hline 28 & Free time & 4.61 & 4.34 & 1.33 & 0.188 \\
\hline 29 & Recognition & 4.67 & 4.32 & 1.64 & 0.107 \\
\hline 30 & Basic salary & 4.67 & 4.58 & 0.43 & 0.668 \\
\hline
\end{tabular}

Note. Significant factors are in bold.

Source: own data processing.

Following mentioned results we can state that employees appreciate good work team and interpersonal relationships. These factors belong to so-called general needs and requirements of teachers at primary schools. Workplace safety as well as mental effort are factors very often discussed and are likely to reflect the situation at primary schools in the Eastern Slovakia. When evaluating questionnaires by means of t-test (Table 3) we determined significant differences in following motivation factors: good work team, name of the school, supervisor's approach, individual decision making, job safety and mental effort. Differences in working relationships between teaching staff in rural and urban areas can affect the choice of motivation factors. In general, community cohesion is much more typical for people living in countryside and, on the contrary, individualism is a typical trait of people from towns. People in countryside are closer to each other and are more willing to provide 
help.

In 2014 the level of general motivation of employees in Slovakia was analysed. 8424 respondents, by using stratified sampling, participated in the analysis (Graph 1). We compared motivation of employees of other Slovak industries to motivation of primary school staff in rural and urban areas to determine differences (Table 4). Significant differences were determined only in factors: atmosphere in the workplace (differences within the urban and rural area), good working team, supervisor's approach and basic salary (differences within the urban area).

Following the analysis we can draw a conclusion that motivation needs of teachers in Slovakia are minimally different from the needs of employees of other Slovak industries. Primary school staff appreciates very similar motivation factors as other employees of Slovak industries. Differences are mainly in the issue of safety and stress in the workplace. Name of the school, individual decision making and interpersonal relationships are factors considered important by teachers. The results of comparison show differences in priorities of teachers at primary schools who know that what separates them from the rest of the pack is the heart and soul they bring into the classroom.

Table 4. Reviewing of significant difference of employee motivation with motivation of teachers at primary schools in rural and urban areas

\begin{tabular}{|c|c|c|c|c|c|c|}
\hline S.N. & & $\begin{array}{c}\varnothing \\
\text { Urban } \\
\text { areas }\end{array}$ & $\begin{array}{c}\varnothing \\
\text { Rural } \\
\text { areas }\end{array}$ & $\begin{array}{c}\varnothing \\
\text { Slovak } \\
\text { Republic } \\
2014\end{array}$ & $\begin{array}{c}\mathrm{P} \\
\text { value } \\
\text { urban } \\
\text { areas }\end{array}$ & $\begin{array}{c}\mathrm{P} \\
\text { value } \\
\text { rural } \\
\text { areas }\end{array}$ \\
\hline 1 & Atmosphere in the workplace & 4.67 & 4.71 & 4.42 & 0.004 & 0.032 \\
\hline 2 & Good work team & 4.56 & 4.87 & 4.45 & 0.027 & 0.057 \\
\hline 3 & Fringe benefits & 4.61 & 4.47 & 4.33 & 0.424 & 0.965 \\
\hline 4 & Physical effort at work & 3.88 & 3.50 & 3.80 & 0.171 & 0.431 \\
\hline 5 & Job security & 4.89 & 4.88 & 4.45 & 0.318 & 0.348 \\
\hline 6 & Communication in the workplace & 4.72 & 4.66 & 4.29 & 0.920 & 0.309 \\
\hline 7 & Name of the company & 4.18 & 3.58 & 3.84 & 0.465 & 0.179 \\
\hline 8 & Opportunity to apply one's own ability & 4.65 & 4.42 & 4.04 & 0.155 & 0.174 \\
\hline 9 & Workload and type of work & 4.47 & 4.53 & 4.09 & 0.425 & 0.398 \\
\hline 10 & Information about performance result & 4.41 & 4.29 & 4.00 & 0.302 & 0.453 \\
\hline 11 & Working time & 4.44 & 4.29 & 4.22 & 0.898 & 0.441 \\
\hline 12 & Work environment & 4.5 & 4.61 & 4.21 & 0.352 & 0.154 \\
\hline 13 & Job performance & 4.59 & 4.53 & 4.14 & 0.274 & 0.502 \\
\hline 14 & Career advancement & 4.18 & 4.18 & 4.00 & 0.273 & 0.513 \\
\hline 15 & Competences & 4.41 & 4.16 & 3.84 & 0.214 & 0.420 \\
\hline 16 & Prestige & 3.88 & 3.71 & 3.75 & 0.805 & 0.287 \\
\hline 17 & Supervisor's approach & 4.83 & 4.47 & 4.38 & 0.018 & 0.085 \\
\hline 18 & Individual decision making & 4.71 & 4.32 & 3.97 & 0.494 & 0.733 \\
\hline 19 & Self-actualization & 4.61 & 4.32 & 3.95 & 0.477 & 0.773 \\
\hline 20 & Social benefits & 4.41 & 4.08 & 4.16 & 0.621 & 0.053 \\
\hline 21 & Fair appraisal system & 4.71 & 4.39 & 4.41 & 0.061 & 0.0587 \\
\hline 22 & $\begin{array}{l}\text { Stress (stress elimination, workplace } \\
\text { safety) }\end{array}$ & 4.83 & 4.45 & 4.13 & 0.661 & 0.271 \\
\hline 23 & Mental effort & 4.67 & 4.24 & 4.00 & 0.060 & 0.073 \\
\hline 24 & Mission of the school & 4.59 & 4.29 & 3.91 & 0.503 & 0.358 \\
\hline
\end{tabular}




\begin{tabular}{lllllll}
\hline 25 & Region's development & 4.29 & 4.13 & 3.84 & 0.085 & 0.925 \\
26 & Education and personal growth & 4.28 & 4.34 & 4.06 & 0.001 & 0.001 \\
27 & Relation to the environment & 4.47 & 4.45 & 3.91 & 0.333 & 0.525 \\
28 & Free time & 4.61 & 4.34 & 4.14 & 0.232 & 0.695 \\
29 & Recognition & 4.67 & 4.32 & 4.18 & 0.271 & 0.930 \\
30 & Basic salary & 4.67 & 4.58 & 4.60 & $\mathbf{0 . 0 3 2}$ & 0.309 \\
\hline
\end{tabular}

Note. Significant factors are in bold.

Source: own data processing.

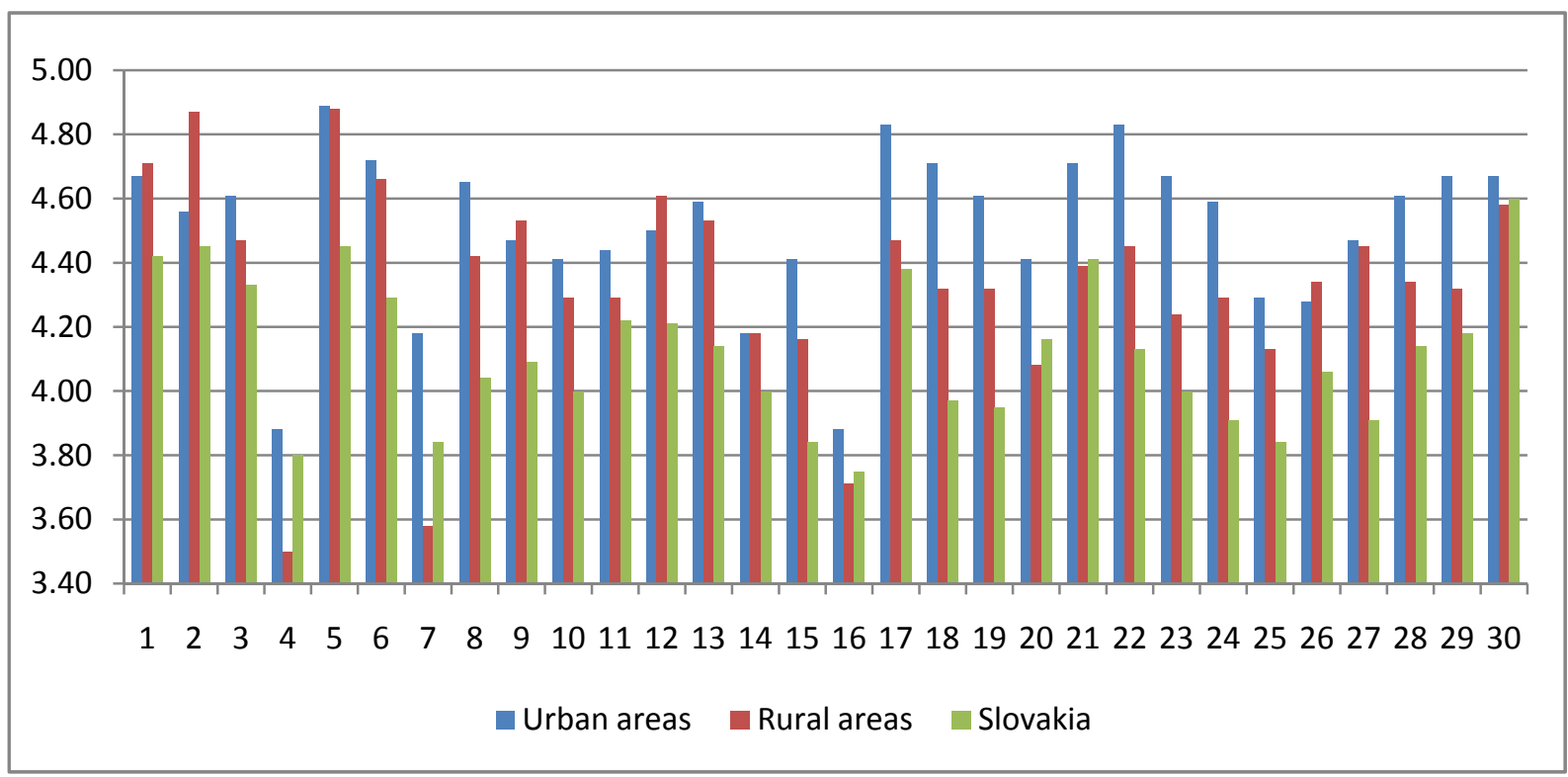

Graph 1. Comparison of average values of differences in employee motivation of teachers at primary schools in the urban, rural areas and other employees in Slovak industries

Source: own data processing.

\section{Conclusions}

Following the findings we can state that employees, despite the recession, are fully aware of the importance of job security and the fact that employers cannot offer them desired financial rewards. Therefore employers should focus on the process of motivation through motivation factors based on interpersonal relationships and job security. On the basis of detailed analysis of individual motivation factors we can assume that motivation through these factors will increase and employees will consider them more important. Very similar order of the most important motivation factors in the rural and urban areas was quite surprising for us. The following conclusions can be drawn from our analysis - despite various teachers' work environments it may be possible to create a unified motivation programme that suits all employees. Factors motivating employees in the rural as well as in urban areas (Table 2) should be in the centre of the motivation programme, especially group of factors related to relationships in the workplace (atmosphere in the workplace, communication in the workplace, supervisor's approach, mental effort and recognition) and the group of factors related to the employee reward system (basic salary, work environment, fringe benefits, workload and type of work, fair appraisal system, workplace safety). The number one priority for employees-teaching staff is job security.

At the present time many organisations do not want or do not consider important to train and to develop their own employees. It is a question of money or lack of interest of employees. System used at Slovak schools puts pressure on teachers to enhance their skills systematically. However, it is unclear if they are also motivated. In the future, results of education in the society, decline in the quality of teacher performance, decline in the quality of education may reflect current reality. Therefore top managers, who run schools, may think carefully about 
education-related costs compared to other costs. According to Teplická (2004) motivation factors were classified as saving opportunity. During financial crisis the most important factors related to the mentioned issue are good name of the organisation or brand, but also continuous quality improvement-performance quality as well as service quality. Organisational values cover fulfilling tasks as well as behaviour in the workplace. Effective communication, openness but especially information about changes is fundamental to success (Kampf \& Bucháčková, 2005; Samáková et al., 2013). Moreover, in the future we can aim at process management (Závadská et al., 2013), where motivation should be an active process in each organisation (Stacho et al., 2013).

The objective of the paper was to compare the level of motivation at Slovak primary schools in rural and urban areas. The statement that in the area of motivation factors there are no differences in needs of teaching staff at Slovak primary schools in urban and in rural areas, is the result of the paper. This implies that similar motivation programmes can be created for employees-teachers from towns and countryside. Creating motivation programmes is a difficult and expensive activity for each organisation. Its effectiveness is influenced by exact employee analysis. At the present time motivation programme can be created upon the average significance of individual motivation factors what is an important finding for the Ministry of Education but also for the top school management. Therefore, job security and trustworthy interpersonal relationships are essential factors for employees-teachers during recession. Effective communication is a key point in this process. Nevertheless, employers have not paid enough attention to this need yet. In the future meeting the needs of employees can cause the changes in their motivation requirements. Therefore we suggest the organisation to update motivation programme from time to time.

\section{Acknowledgements}

This paper has been supported by the project IGP 3/2013 The Key Functions of Personnel Management in the Context of Development of Organisations Operating in the Slovak Republic and Czech Republic

\section{References}

Blašková, M. (2010). Creative Proactive-concluding Theory of Motivating. Business: Theory and Practice, 11(1), 39-48. http://dx.doi.org/10.3846/btp.2010.05

Bolfíková, E., Hrehová, D., \& Frenová, J. (2010). Manager's decision-making in organizations-Empirical analysis of bureaucratic vs. learning approach (Conference Paper). Zbornik Radova Ekonomskog Fakultet au Rijeci, 28(1), 135-163.

Hitka, M. (2009). Model analýzy motivácie zamest nancovvý robných podnikov, Zvolen, Technick áuniverzit avo Zvolene.

Hitka, M., \& Balážová, Ž. (2015). The impact of age, education and seniority on motivation of employees. Journal Business: Theory and Practice, 16(1), 113-120. http://dx.doi.org/10.3846/btp.2015.433

Hitka, M., Hajduková, A., \& Balážová, Ž. (2014). Impact of the economic crisis on the change in motivation of employees of wood working industry enterprise. http://dx.doi.org/10.5552/drind.2014.1303

Hitka, M., Hajduková, A., \& Vacek, V. (2012). Porovnanieúrovnemotiváciezamestnancov v podniku Slovenska a Vel'kej Británie. Journal Sociálno-ekonomická revue 3/2012. TnUAD.

Kampf, R., \& Bucháčková, P. (2005). User Benefits and Wider Economic Impacts of Infrastructural Project Investment. Journal of Information, Control and Management Systems, 3(2), 91-96.

Kariková, S. (2006). Kapitoly z pedagogickej psychológie. Žilina: IPV.

Kucharčíková, A. (2014). The importance of identification and analysis of educational needs for investment in humancapital. Komunikacie, 16(3), 86-92.

László, K. (2004). Motivácia v edukačnomprostredí. Banská Bystrica: UMB.

Lauermann, F. (2014). Teacher responsibility from the teacher's perspective. International Journal of Educational Research, 65, 75-89. http://dx.doi.org/10.1016/j.ijer.2013.09.005

Linhartová, L., \& Urbancová, H. (2012). Results of analysis of employee mobility: Factors affecting knowledge continuity. Acta Universitatis Agriculturaeet Silviculturae Mendelianae Brunensis, LX(4), 235-244.

Manniová, J. (2008). Učitel’ v procesevýchovy a vzt’ahov. Bratislava: Axima.

Niermeyer, R., \& Seyffert, M. (2005). Jak motivovatsebe a svéspolupracovniky. Praha: Grada Publishing.

Pajtinková, B. G., \& Gubíniová, K. (2012). Udržatelný marketingový manažment. Trenčín: IAM press.

Samáková, J., Šujanová, J., \& Koltnerová, K. (2013). Project communication management in industrial 
enterprises. 7th European Conference on Information Management and Evaluation, ECIME 2013 (pp. 155-163).

Šatanová, A., Závadský, J., Sedliačiková, M., Potkány, M., Závadská, Z., \& Holíková, M. (2014). How Slovak small and medium manufacturing enterprises maintain quality costs: an empirical study and proposal for a suitable model. Total Quality Management and Business Excellence, 25. http://dx.doi.org/10.1080/14783363.2014.916477

Sedmák, M., (2002). Manažment. IURA EDITION, Ltd.

Stacho, Z., \& Stasiak-Betlejewska, R. (2014). Approach of organisations operating in Slovakia to employee's performance evaluation. Ekonomičnijčasopis, XXI(5-6), 83.

Stacho, Z., Urbancová, H., \& Stachová, K. (2013). Organisational arrangement of human resources management in organisations operating in Slovakia and Czech Republic. Acta Universitatis Agriculturaeet Silviculturae Mendelianae Brunensis, LXI(7), 2787-2799. http://dx.doi.org//10.11118/actaun201361072787

Stachová, K., \& Stacho, Z. (2010). Employee allocation in Slovak companies. Business: Theory and Practice, 11, 39-48. http://dx.doi.org/10.3846/btp.2013.35

Štatistickýúrad Slovenskejrepubliky. (2012). Demografia 2012-Stavobyvatel'stva v regiónoch SR v roku 2012. Portal statistics. Bratislava: Štatistickýúrad Slovenskejrepubliky, 2012. Retrieved from http://portal.statistics.sk/files/Odbory/odb_410/el_publikacie/1_demostav2012.pdf

Teplická, K. (2004). Progresívne trendy riadeniavýrobnýchpodnikov. Ekonomie a management, 7, 26-31.

Turek, I. (2008). Didaktika. Bratislava: Iuraedition.

Urbancová, H. (2012). Conditions and principles for knowledge continuity ensuring in organizations. Scientia Agriculturae Bohemica, 4, 166-172. http://dx.doi.org/10.7160/sab.2012.430407

Urbancová, H. (2012). Results of analysis of organisational culture in organisations in the Czech Republic and Slovak Republic. Acta Universitatis Agriculturaeet Silviculturae Mendelianae Brunensis, LX(7), 433-440.

Vetráková, M. (2011). Ludskézdrojea ichriadenie. EF UMB Banská Bystrica. Bratia Sabovci, Ltd.

Wahab, J. A., Hanim A., H., Zainal, S., \& Rafik, F. (2013). The Relationship between Headteachers' Distributed Leadership Practices and Teachers' Motivation in National Primary Schools. Asian Social Science, 9(16), 161-167. http://dx.doi.org/10.5539/ass.v9n16p161

Watt, H. M. G., Richardson, P, W., \& Wilkins, K. (2014). Profiles of professional engagement and career development aspirations among USA preservice teachers. International Journal of Educational Research, 65, 23-40. http://dx.doi.org/10.1016/j.ijer.2013.09.008

Wosnitza, M., Helker, K., \& Lohbeck, L. (2013). Teaching goals of early career university teachers in Germany. International Journal of Educational Research, 65, 90-103. http://dx.doi.org/10.1016/j.ijer.2013.09.009

Zámečník, R. (2007). Personnel controlling as a part of the management controlling system in an enterprise. Ekonomie a Management, 10(2), 29-36.

Závadská, Z., Závadský, J., \& Sirotiaková, M. (2013). Process Model and its Real Application in the Selected Management Areas. Ekonomie a Management, 16(1), 113-127.

\section{Copyrights}

Copyright for this article is retained by the author(s), with first publication rights granted to the journal.

This is an open-access article distributed under the terms and conditions of the Creative Commons Attribution license (http://creativecommons.org/licenses/by/3.0/). 